\section{Robert Picard apresenta, finalmente em português, as tensões entre $o$ valor jornalístico e o valor do consumidor de notícias}

DOI $10.1590 / 1809-5844201419$

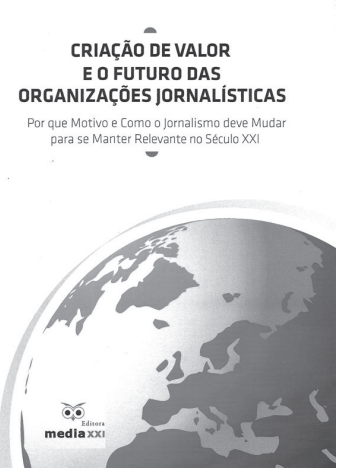

PICARD, Robert G. Criação de valor e o futuro das organizações jornalísticas: Por que motivo e como o jornalismo deve mudar para se manter relevante no século XXI. Porto: Editora Media XXI, 2013. 170p.

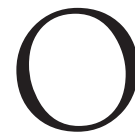

livro Criação de valor e o futuro das organizações jornalísticas, do professor e pesquisador Robert G. Picard, contém afirmações que podem assustar alguns teóricos da Comunicação do novo milênio: ainda há espaço para as mídias tradicionais. $\mathrm{O}$ autor afirma ainda que elas precisam impor mais valor ao conteúdo que produzem, incluindo a possibilidade de cobrança pela informação disponível em outras plataformas.

Uma leitura mais atenta do livro, porém, revela que a grande questão não está na adaptabilidade das empresas já estabelecidas ao mundo dinâmico intermediado pela internet. A maior dificuldade

\footnotetext{
* Doutorando em Comunicação pela Universidade do Estado do Rio de Janeiro (UERJ), jornalista, professor e mestre em Ciências Sociais pela Universidade Estadual de Londrina (UEL-PR). Londrina-PR, Brasil.
} 
seria balancear o "valor" da informação calculado pelas empresas (em uma equação que muitas vezes reduz o consumidor à audiência para anunciantes) com o "valor" determinado pela sociedade (seja o leitor, espectador, ouvinte ou usuário) a este ou aquele conteúdo jornalístico envolvendo interesse público, poder de mobilização e mudanças nas vidas individual ou coletiva da população.

"O resultado é que as organizações noticiosas fornecem algo para todas as pessoas, mas pouco para cada pessoa", afirma Picard (p.94), reforçando ainda que conteúdo em grande quantidade "produz um valor limitado e gera audiências que, por vezes, estão dispostas a abdicar do consumo”. A solução seria reestabelecer o valor social (a importância institucional da imprensa) junto ao valor meramente econômico.

Picard teve a trajetória iniciada nos Estados Unidos e consolidada na Europa. O professor norte-americano passou por instituições de pesquisa na França, Suécia, Finlândia e Portugal até se estabelecer na Universidade de Oxford (Inglaterra), onde dirige o Reuters Institute. A experiência como consultor de comissões parlamentares e de empresas na área de Comunicação faz do autor um especialista em economia das mídias e negócios envolvendo organizações midiáticas, tema um pouco espinhoso dentre os acadêmicos da Comunicação no Brasil.

Autor de 27 livros, entre eles o clássico Media economics (Sage Publications, 1989), esta é a primeira publicação dos estudos de Picard em nossa língua (português de Portugal). Atenta ao mercado brasileiro, a editora lusitana Media XXI trouxe o pesquisador para lançar o livro no Brasil, em parceria com a Universidade do Estado do Rio de Janeiro (UERJ), durante o I Colóquio Internacional de Jornalismo ${ }^{1}$.

Este resenhista acompanhou a palestra de Picard durante o Colóquio, no qual ele ressaltou a importância da internet, mas principalmente como mediadora de comportamentos. Segundo o pesquisador, as organizações jornalísticas precisam pensar que "o público adota cada vez mais valores e normas" do mundo digital.

${ }^{1}$ Evento realizado em 12 de agosto de 2013, na UERJ, e coordenado pela professora Dra. Sonia Virginia Moreira. 
"Os valores e as práticas estão conectados com o mundo. É preciso compreender que a educação dos jovens, por exemplo, passa por um processo colaborativo feito de maneira informal”.

Tais apontamentos aparecem esmiuçados no livro, que começa tratando do pedregoso caminho das organizações midiáticas (com foco no Jornalismo) nas primeiras décadas deste século. Picard apresenta dados que evidenciam problemas estratégicos na atividade noticiosa e aponta sinais que reforçam o desejo do público por notícias que extrapolem a pura divulgação, transitando por um processo analítico amparado em investigação e boas informações obtidas com exclusividade.

Nos capítulos dois e três, são recuperados referenciais econômicos, sociológicos e filosóficos do termo, assim como abordagens teóricas que auxiliam na reconfiguração do valor. No quarto capítulo, Picard propõe estratégias para reverter a crise de valor entre organizações midiáticas e consumidores a partir de sete abordagens relevantes (p. 94-114), inclusive com gráficos detalhados. Dentre as estratégias, destacam-se o aumento da abrangência geográfica, o fornecimento de notícias exclusivas, valorização de informações especializadas e a convergência das notícias e informações existentes.

$\mathrm{Na}$ transição entre do quinto para o sexto (e último) capítulo, o pesquisador de Oxford discute condições gerenciais para aumentar o valor da notícia e desfia críticas às organizações que retiram investimentos da área de conteúdo e alocam recursos ao marketing, vendas ou à adaptação (sem reformulação) de informações para o ambiente online e de telefonia móvel. "Se o público não gostar do que é oferecido, do momento em que é oferecido ou do custo em termos de tempo e dinheiro, pode facilmente trocar os seus provedores de notícias ou informação ou recusar o consumo" (p.150).

Com tais análises, o livro de Robert Picard mostra que o futuro das organizações jornalísticas não passa apenas pelos gestores e pela redação: está também nas mãos do consumidor. "A menos que as organizações noticiosas aumentem o valor que criam nestes processos sociais, a sua importância nos processos de participação democrática e governamentais continuará a declinar”, alerta. 